\title{
Top Tips in 2 minutes
}

\author{
'Where is the wisdom we have lost in \\ knowledge? \\ Where is the knowledge we have lost \\ in information?"1
}

And where indeed is the information we have lost in data? Anyway, here's a really good idea that might help. We don't have hand outs at our postgraduate sessions any more, we ask instead for a 'Top Tip'. We asked authors to imagine this:

'You are about to give a talk to a group of interested GPs, you were going to speak for 1 hour at an important international conference. As bad luck would have it, you and a group of GPs have got stuck in the lift and your talk has been cancelled. However, you will be rescued in 2 minutes. Knowing what an interesting speaker you are and how passionately you feel about this area of your work, your colleagues plead with you to pass on some essential pearls of wisdom. What are your top tips in 2 minutes?

Tell your captive audience (all of whom will be blessing the name of Elisha Graves Otis) ${ }^{2}$ why the subject is important/interesting; how to look for specific features in the consultation; what next and when for investigations and further management, and finally, a web link or two, both for yourself and your patient.

Top Tips in 2 minutes are snappy, to the point, up-to-date and totally unstuffy. Since the word limit is no more than one side of A4 your enthusiasm will not be over taxed but if you are feeling keen you can always use the web links section to find out more. Our first Top Tip in 2 minutes is on chronic kidney disease. Why? Because it's 'been around forever, but important now because of eGFR and the QOF'. ${ }^{3}$

We will be publishing one Top Tip in 2 minutes a month for the next year, and while we guarantee to inform and entertain, we certainly don't intend to be too serious.

Why the humour? Evidence-based of course! Researchers have found that a sense of humour reduces mortality. ${ }^{3}$ Kidney patients who participated in the study answered questions about age, sex, race, education, quality of life, and sense of humour. All of the patients studied were on dialysis. Patients who scored relatively high on sense of humour were $30 \%$ less likely to die within 2 years. No other patient characteristics could predict life or death within 2 years as strongly as the score for sense of humour.

\section{Ruth Bastable \\ Sarah Rann \\ Vinny Barker}

\section{Acknowledgements}

Thanks to Addenbrookes PGMC. Top Tips in 2 minutes would not have happened without their help.

\section{REFERENCES}

1. Eliot TS. Choruses from 'The Rock'. In: Eliot TS. Selected poems. London: Faber and Faber, 1961: 97.

2. Otis EG. Inventor of the safety lift. http://www.otis.com/ (accessed 27 Nov 2007).

3. American Association of Kidney Patients. Humor extends life.

http://www.aakp.org/newsletters/RenalFlash/January-2007/Humor-Extends-Life/ (accessed 27 Nov 2007).

DOI: 10.3399/bjgp08X263956 


\section{Top Tips in 2 minutes: Chronic kidney disease.}

\begin{tabular}{|c|c|}
\hline How: & $\begin{array}{l}\text { Example: A laboratory result comes back on one of your patients, an } 80 \text {-year-old woman, showing that creatinine is } \\
125 \mu \mathrm{mol} / \mathrm{l} \text {, which doesn't seem too bad, but eGFR is calculated as } 38 \mathrm{ml} / \mathrm{min} \text {, CKD stage } 3 \text {. }\end{array}$ \\
\hline & $\begin{array}{l}\text { Proceed as follows: } \\
\text { 1. Remember that CKD stage } 3 \text { affects } 3-4 \% \text { of the population and } 30 \% \text { of people over } 70 \text { years, most of whom do not } \\
\text { need referral to renal services. } \\
\text { 2. Do not tell the woman and her family that she has CKD: say that her kidney function is slightly reduced, as it is in } \\
\text { one-third of older patients. } \\
\text { 3. Check if creatinine has been measured before: if so, is it stable? If not, repeat in near future. } \\
\text { 4. History - previous kidney problems: urinary tract infection, haematuria, stones, protein in urine (pregnancies, medicals), } \\
\text { episodes of swelling, and family. } \\
\text { 5. History - cardiovascular risk factors. } \\
\text { 6. Examination - is the bladder palpable (especially elderly men)? If it is - organise urgent ultrasound of urinary tract and } \\
\text { discuss with urological services. } \\
\text { 7. Examination - check blood pressure. }\end{array}$ \\
\hline What next and when: & CKD stage defined by eGFR \\
\hline
\end{tabular}

\begin{tabular}{ccl}
\hline Stage & $\begin{array}{c}\text { eGFR } \\
(\mathrm{ml} / \mathrm{min})\end{array}$ & Comment \\
\hline 1 & $>90$ & Must have other evidence of kidney disease \\
\hline 2 & $60-90$ & Must have other evidence of kidney disease \\
\hline 3 & $30-60$ & \\
\hline 4 & $15-30$ & \\
\hline 5 & $<15$ & \\
\hline
\end{tabular}

\section{CKD stages 1 and 2}

1. Few patients with CKD 1 or 2 require referral to renal services.

2. Urine - stick test for blood and protein; quantitate proteinuria with albumin creatinine ratio (ACR). Refer to renal services if no blood and ACR $>65 \mathrm{mg} / \mathrm{mmol}$ or blood and ACR $>30 \mathrm{mg} / \mathrm{mmol}$.

3. In general practice - annual monitoring of creatinine, potassium, cholesterol, and ACR.

4. Blood pressure control - ' $130 / 80 \mathrm{mmHg}$ maximum, or $125 / 75 \mathrm{mmHg}$ in patients with urinary ACR $>65 \mathrm{mg} / \mathrm{mmol}$ (approximately equivalent to $\geq 2$ on dipstick test)' is the ideal ... but common sense must prevail. Quote from: http://www.renal.org/eGFR/eguide.html (also cited below)

\section{CKD stage 3}

1. Not all patients with CKD3 require referral to renal services.

2. Urine - stick test for blood and protein; quantitate proteinuria with protein or albumin creatinine ratio (P/ACR). Refer to renal services if no blood and PCR $>100 \mathrm{mg} / \mathrm{mmol} / \mathrm{ACR}>65 \mathrm{mg} / \mathrm{mmol}$ or blood and PCR $>45 \mathrm{mg} / \mathrm{mmol} / \mathrm{ACR}>30 \mathrm{mg} / \mathrm{mmol}$.

3. Other blood tests: calcium, phosphate, haemoglobin, and cholesterol.

4. Action - stop poisons (NSAIDs).

5. Blood pressure control - as above.

6. Monitoring - check creatinine and (1) and (2) every 6-12 months and consider referral to renal services if reaches CKD stage 4.

7. May need treatment with phosphate binders, vitamin D analogues, iron, epo - discuss with renal services.

8. Immunisation - influenza and pneumococcal.

\section{CKD stages 4 and 5}

As for stage 3, except (in contrast to Stage 3) please refer to or discuss with renal services, except in patients in whom:

1. All appropriate investigations have been performed and there is an agreed and understood care pathway.

2. Severe renal impairment is part of another terminal illness.

3. Further investigation and management is clearly inappropriate.

Patient information: Patient UK Chronic Kidney Disease - A Summary http://www.patient.co.uk/showdoc/27001285/

Patient leaflet on CKD from RCGP http://www.renal.org/eGFR/resources/PatientCKDinfJan2007.pdf

Web links/references: The short CKD eGuide http://www.renal.org/eGFR/eguide.html

The Infirmary of Edinburgh Renal Unit - really helpful GP guide http://renux.dmed.ed.ac.uk/EdREN/Unitbits/GPinfo.html

Who are you: Dr John Firth, Director of Renal Services, Addenbrookes Hospital, Cambridge.

Date:

October 2007

